\title{
4: 89436901-893700019
}

National Cancer Institute

\section{Source}

National Cancer Institute. 4: 89436901-893700019. NCI Thesaurus. Code C41634.

Physical location of ABCG2_Gene 